\title{
躯体蓄熱システムにおける蓄熱特性の評価に関する実験的研究 AN EXPERIMENTAL STUDY ON THERMAL CHARACTERISTICS OF HEATING/COOLING SYSTEM WITH BUILDING THERMAL MASS STORAGE
}

\author{
中村卓司*，長野克則** \\ Takuji NAKAMURA and Katsunori NAGANO
}

\begin{abstract}
The real-scale experimental unit of HVAC system using building thermal mass storage for a commercial building was constructed and a series of experiment was carried out. The experimental condition varies direction of blowing, flow rate and density of diffuser in order to clarify their influence to the amount of charging energy into the slab. And the thermal storage capacity was analyzed making unit by differential of initial concrete slab temperature and blowing temperature. The result shows that the unit thermal storage capacity was proper, and the unit thermal storage capacity of horizontal blowing is larger than from 1.4 times to 1.9 times as vertical blowing.
\end{abstract}

Keywords: Building thermal mass storage, characteristic of thermal storage, unit thermal storage capacity 躯体蓄熱、蓄熱特性、単位蓄熱量

\section{1. はじめに}

従来より電力負荷平準化のため水蓄熱・水蓄熱システムが開発、 利用されてきたが、近年コンクリートスラブなど躯体を蓄熱体とし て利用する躯体蓄熱システムが注目を集めるようになってきた。躯 体蓄熱の特長として、夜間電力の利用によるランニングコストの低 減、および機器容量の削減によるイニシャルコストの低減といった 蓄熱システムの一般的な利点に加え、(1)既にある建物躯体を利用す ることで、高価な水・氷蓄熱の蓄熱槽・熱源機の容量を削減できる、 (2)身区体から直接室内に放熱されるため 2 次側空調設備の容量を削減 できる、(3)蓄冷された躯体により放射冷房効果を期待できるといっ たメリットがある半面、主蓄熱体であるスラブへの蓄熱・放熱特性 が明らかでないという問題点が残されていた。

この原因として、蓄熱時のスラブへの空気の吹付けが局所的にな り蓄熱に分布ができるため、その効果の把握が困難であったことが 挙げられる。また、従来の性能評価は実建物での測定が多く、それ らは外乱の影響を受けている。これに対し、スラブ温度を詳細に測 定でき再現性の高い実大規模の試験装置が製作され基礎的な実験と 性能評価が行われた。12233

本論文ではさらに、蓄熱量が吹付け方法、風量、温度、天井裹の 梁などに大きく影響を受けることに着目し、これらの影響因子を条 件に試験を行い、条件毎の蓄熱特性を躯体蓄熱の検討に簡易に利用 可能な形に整理することを目的に蓄熱量の新たな評価法の提案を行 った。また、その評価法を用いて蓄熱特性に関し考察を加えた。

\section{2. 試験装置概要 ${ }^{11}$}

\section{1 試験室の概要}

試験装置は清水建設技術研究所の倉庫内に建設した。建物用途は 標準的な事務所ビルを想定し、スラブの熱特性が測定できるように スラブを挟んだ上下 2 層の試験室を設置した。その 1 面は外気の影 響を再現できるように空ガラスのある外壁からなり、外壁の外側は 温度制御のできる外気室を設けた。残りの 5 面は温度対象を想定し 断熱材で仕切る構造とし、実建物の中間階 1 区画を切出した状態と した。各室の寸法は試験室部分が内寸法幅 $6.4 \mathrm{~m}$ 、奥行き $10 \mathrm{~m}$ 、階高 $3.5 \mathrm{~m}$ (上層試験室は $1.5 \mathrm{~m}$ )、外気室部分が内寸法幅 $6.9 \mathrm{~m}$ 、奥行き $5 \mathrm{~m}$ 、 階高 $5.0 \mathrm{~m}$ である。試験室は一般的な事務室を想定し、床は各層共 $\mathrm{OA}$ フロア $(\mathrm{h}=100)$ で、下層試験室天井は $15 \mathrm{~mm}$ 厚の岩綿吸音板から なるシステム天井とした。倉庫内に面する外周部はフォームポリス チレン保温板( $100 \mathrm{~mm}$ 厚の 2 枚重初)で、下層試験室床下はフォーム ポリスチレン保温板 $(50 \mathrm{~mm}$ 厚)、上層試験室天井はロックウール (100mm 厚)で断熱した。図 1 に試験室概要図を示す。

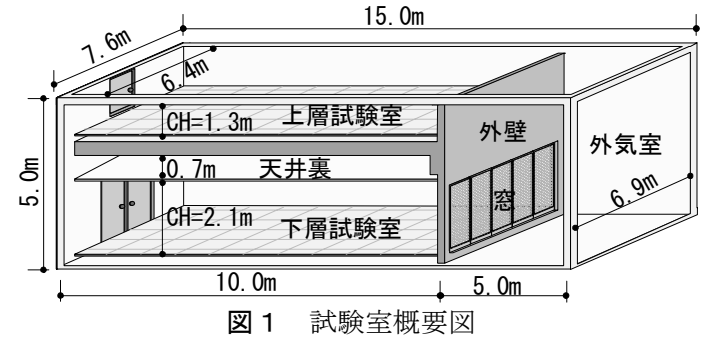

\footnotetext{
* 清水建設株技術研究所 工修

$* *$ 北海道大学大学院工学研究科 教授.工博 


\section{2 空調システム概要}

図 2 に試験装置の空調システム概要を示す。上下試験室は、空冷 ヒートポンプチラーを熱源とする単一ダクト空調方式とした。給気 は天井アネモディフューザー(上層試験室は壁付ディフューザー)吹 出しと床吹出し空調の切替え式とした。還気は、天井チャンバー還 気(下層試験室)と室内還気および床下還気の切替え式とした。これ らの切替えパターンの組み合わせにより、様々な蓄・放熱試験をスケ ジュール運転で行うことができる。外気室は、セパレート型エアコ ンを設置した。

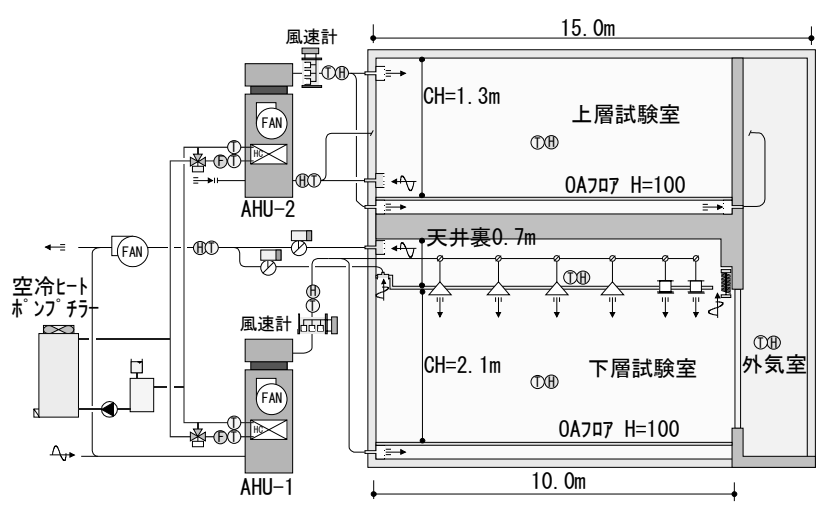

図 2 空調システム概要

\section{3 計測システム}

測定点は風量、給気・還気温湿度、各室温湿度、流量、送水·還水 温度、床スラブ・壁等の表面・内部温度等で、測定点総数は約 300 点である。床スラブは蓄放熱量を可能な限り精度よく算出するため 図 3 に示寸位置に約 150 点の $\mathrm{T}$ 型熱電対を設置した。特にスラブ内 の温度分布の影響を把握するため図 3 (1)の垂直 5 点が 4 箇所、(2) の垂直 3 点が 39 箇所、(3)の垂直 2 点が 4 箇所の温度センサーを設 置した。また、測定間隔は 5 分間でデーターロガーを介しパソコン に取り込んだ。測定機器一覽を表 1 に示す。

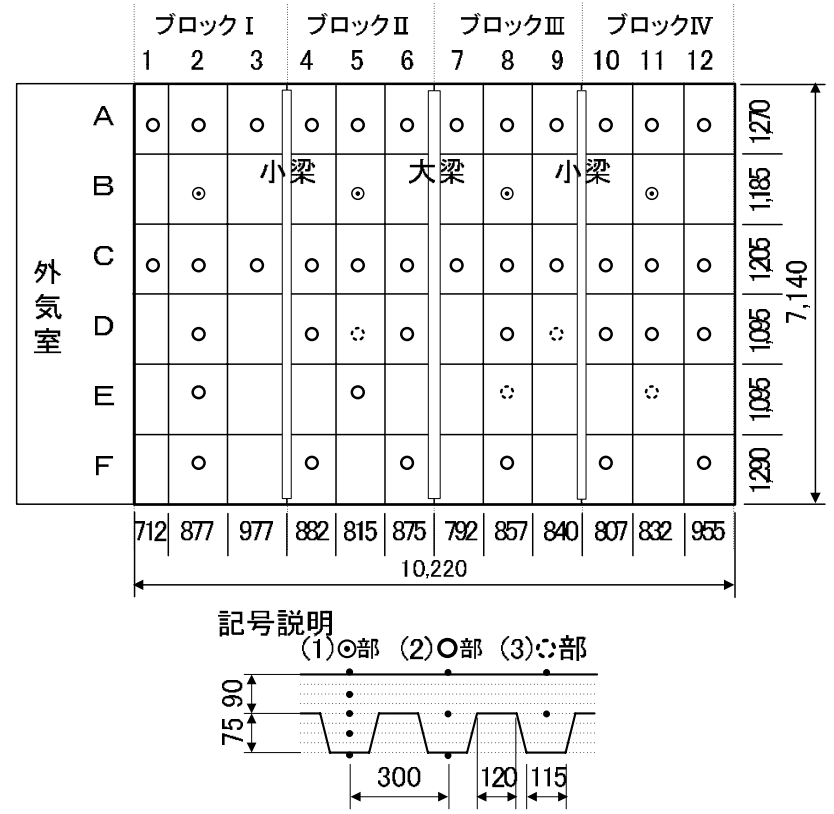

図 3 スラブ温度測定位置
表 1 計測装置一覧

\begin{tabular}{|l|l|}
\hline 測定対象 & \multicolumn{1}{|c|}{ 機器名 } \\
\hline 温度 & $0.32 \phi$ T型熱電対 \\
\hline 表面温度 & $0.1 \phi$ T型熱電対 \\
\hline 風速 & 定置式複合ピト一管センサ、精度 $\pm 0.2 \%$ 以内 \\
\hline 湿度 & 高分子型、精度 $\pm 3 \% R H\left(30 \sim 70 \% 、 25^{\circ} \mathrm{C}\right)$ \\
\cline { 2 - 2 } & $\pm 5 \% \mathrm{RH}\left(20 \sim 80 \% 、 15 \sim 35^{\circ} \mathrm{C}\right)$ \\
\hline \multirow{2}{*}{ 流量 } & 電磁流量計、精度 $\pm 0.8 \%($ 流速 $0.5 \sim 0.7 \mathrm{~m} / \mathrm{s})$ \\
\cline { 2 - 2 } & $\pm 0.6 \%($ 流速 $0.7 \mathrm{~m} / \mathrm{s}$ 以上 $)$ \\
\hline
\end{tabular}

\section{3．躯体蓄熱空調方式の概要と試験条件 \\ 3.1 躯体蓄熱空調方式と試験方法}

蓄熱方式は複数検討されているが、本論文では切替えダンパー方 式の結果について述べる。切替えダンパー方式とは天井ディフュー ザー手前の天井内で切替えダンパーを設けることにより夜間蓄熱時 は天井裏に冷風を吹付けスラブへ蓄熱し、昼間空調時は天井ディフ ユーザーより室内に給気し、天井チャンバー還気時にスラブから放 熱を行うシステムである。切替えダンパー方式の特長としてはシス テムが簡易であるが蓄熱が局所的になることが考えられる。そこで 試験では、スラブへの吹付け方向、風量、吹付け口密度等を変化さ せ影響度の比較を行った。また、過去の実験より蓄熱には梁の影響 が大きいことがわかっているため、梁で囲まれた空間を一単位とし て扱い、これを「ブロック」(約 $2.5 \mathrm{~m} \times 6.4 \mathrm{~m}$ 、約 $\left.16 \mathrm{~m}^{2}\right)$ と呼び検討す ることとした。図 3 に示寸ようにブロック I からブロックIVに分け る。また、ブロックに吹出し口を設けられなかった場合を想定し、 梁をくぐることによる蓄熱量の減少の検討を行った。その他、具体 的な試験条件は次節に示す。

\section{2 試験条件}

\section{2.1 試験条件}

表 2 に今回設定した試験条件を示す。試験番号 1 (ケース記号 $\mathrm{V}-$ $1)$ を「標準仕様」とし、その他の条件は常に標準仕様と 1 項目だけ 異なる条件の試験となるように設定した。表中の吹付け方式「垂直」 (吹出し口 : 口径 $\mathrm{D}=200 \phi$ ) とはスラブ下 $1.5 \mathrm{D}$ の位置から垂直に吹付 ける方式である。「水平」(吹出し口：600L $\times 25 \mathrm{H}$ のスリット)の場合 にはデッキプレートの波に直角方向に、「穴明きダクト」(吹出し口：

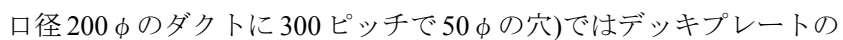
波の方向に空気を吹付ける。図 4 から図 8 に各方式の吹出し口の位 置を示す。吹付け風量は 2 段階設定した。床面積当たりの風量 $28 \mathrm{~m}^{3} /\left(\mathrm{m}^{2} \cdot \mathrm{h}\right)$ （平均風速 $3.2 \mathrm{~m} / \mathrm{s}$ ） は昼間の空調時と同等の風量とし、 全吹出し口の合計でおよそ $1800 \mathrm{CMH}$ である。試験番号 $2(\mathrm{~V}-2)$ 風量 $14 \mathrm{~m}^{3} /\left(\mathrm{m}^{2} \cdot \mathrm{h}\right)$ は夜間のみこれの半分の風量とした。ブロック当た りの吹出し口個数の相違試験では、標準の吹出し口数(ブロック当た り 1.5 個)に追加、削除を行い試験番号 $3(\mathrm{~V}-3)$ は図 5 に示寸位置に

\begin{tabular}{|c|c|c|c|c|c|c|}
\hline \multirow{3}{*}{$\begin{array}{l}\text { 試 } \\
\text { 番 } \\
\end{array}$} & \multirow{3}{*}{ ケース記号 } & (1) & (2) & (3) & (4) & (5) \\
\hline & & \multirow{2}{*}{ 吹付け方式 } & 吹付け風量 & $\begin{array}{l}\text { ブ听当りの } \\
\text { 吹出し個数 }\end{array}$ & 梁くぐり回数 & 吹出し温度 \\
\hline & & & {$\left[\mathrm{m}^{3} /\left(\mathrm{m}^{2} \cdot h\right)\right]$} & [個/ブロック] & [回] & {$\left[{ }^{\circ} \mathrm{C}\right]$} \\
\hline 1 & $\mathrm{~V}-1$ & 垂直 & 28 & 1.5 & 0 & 15 \\
\hline 2 & $\mathrm{~V}-2$ & 垂直 & 14 & 1.5 & 0 & 15 \\
\hline 3 & $V-3$ & 垂直 & 28 & 2 & 0 & 15 \\
\hline 4 & V-4 & 垂直 & 28 & 1 & 1or2 & 15 \\
\hline 5 & V-5 & 垂直 & 28 & 1.5 & 0 & 11 \\
\hline 6 & $V-6$ & 垂直 & 28 & 1.5 & 0 & 9 \\
\hline 7 & $\mathrm{H}-1$ & 水平 & 28 & 1.5 & 0 & 15 \\
\hline 8 & D-1 & 穴明きダクト & 28 & - & 0 & 15 \\
\hline
\end{tabular}




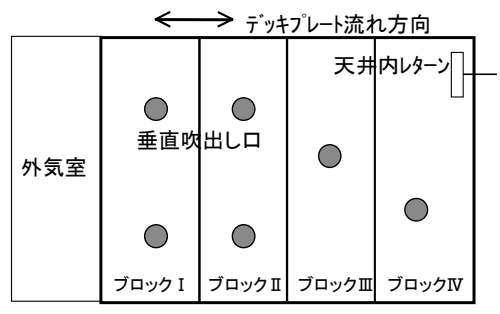

図 $4 V-1$ (標準) の吹出し口位置

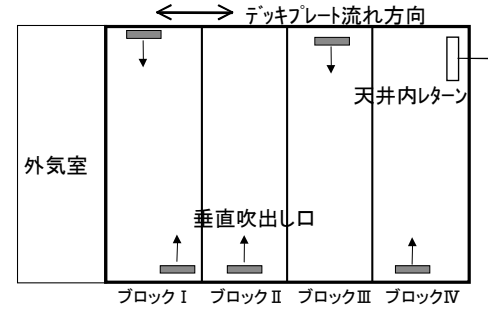

図 $7 \mathrm{H}-1$ の吹出し口位置

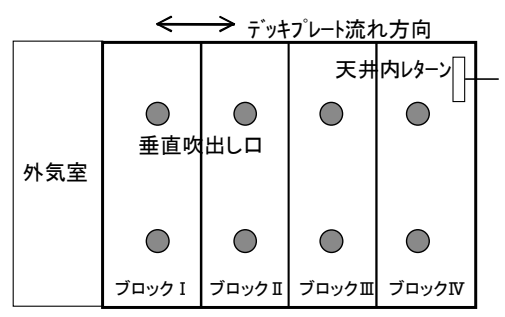

図 $5 \mathrm{~V}-3$ の吹出し口位置

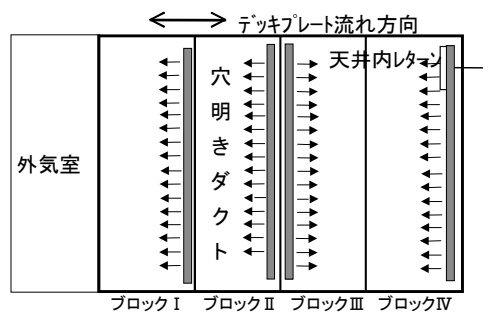

図8 D - 1 の吹出し口位置

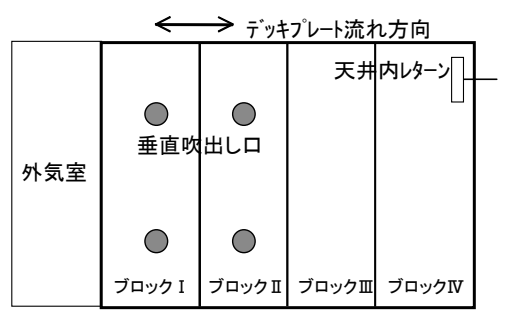

図 $6 \mathrm{~V}-4$ の吹出し口位置

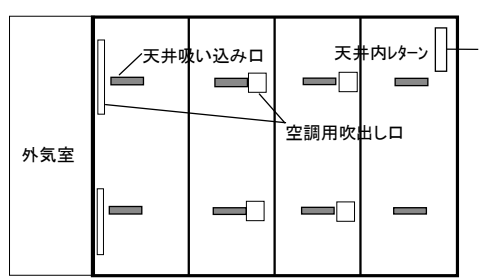

図 9 居室吹出しとレターン位置
2 個の場合の吹出し口を設けた。試験番号 $4(\mathrm{~V}-4)$ は梁をくぐる回 数による蓄熱量の減少を測定する試験で、図 6 に示寸吹出し口位置 とした。ブロック III、ブロックIVには吹出しロが無い。吹出し温度 は標準の $15^{\circ} \mathrm{C}$ 他、 $11^{\circ} \mathrm{C} 、 9^{\circ} \mathrm{C}$ の計 3 種類設定した。また、蓄熱時 間は全ケースで 3:00 から 8:00 までの 5 時間とした。試験期間は躯 体の熱容量を考慮し数日実施し、安定した日のデータを用いた。ま た、吹出し温度など環境が大きく異なるケースでは 1 週間程度の試 験を実施した。図 9 に空調時の室内吹出し口、天井吸い込み位置と 天井内のレターン位置を示す。

\section{2.2 外乱および空調、室内発熱条件}

外気室は常時 $30^{\circ} \mathrm{C}$ 一定制御とし、日射発熱は図 10 に示寸スケジ ユールで白熱球による模擬発熱を下層試験室空内側に加えた。空調 は上層、下層試験室とも空調時間( 8 時〜 20 時)は室温 $26^{\circ} \mathrm{C}$ 設定、蓄 熱時は天井裏吹出し温度一定制御とし、試験条件により吹出し温度 を変更した。室発熱は事務所を想定し、図 10 に示す室内模擬発熱を 蛍光灯、および白熱電球により加えた。

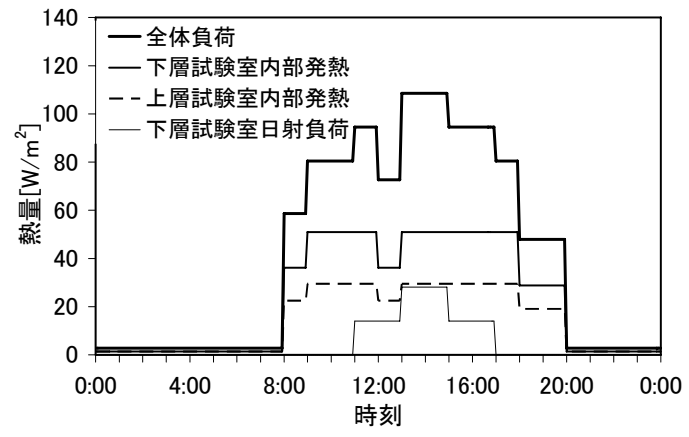

図 10 内部発熱スケジュール

\section{4. 試験結果、および考察}

\section{1 試験結果の再現性の評価}

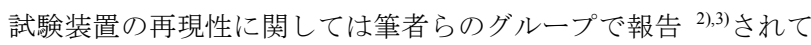
いる。ただし、蓄熱の評価には放熱を含めた一日を通しての試験の 再現性を確認しておく必要があるため、本試験におけるスラブ温度 の日変化の評価を行った。スラブ温度は蓄熱の局所性を考慮するた め、以下の方法により平均温度を算出した。まず、仮想的にスラブ 内部をメッシュ分割し、温度測定メッシュは測定值を測定していな
いメッシュは近傍メッシュの測定值より補完してメッシュ温度を求 め、これをメッシュの代表温度とした。メッシュ分割は図 3 に示す ように水平面では間口方向は 6 分割、奥行き方向は 12 分割し、一つ のメッシュの受け持つ面積が $1 \mathrm{~m}$ 四方以下となるようにした。垂直 方向は上層、中層、下層に 3 分割した。今回使用したデッキプレー トは凹凸があるため凹凸各部を 3 分割し加重平均して厚さを設定し た。加重平均厚さは上層 $46 \mathrm{~mm}$ 、中層 $40 \mathrm{~mm}$ 、下層 $40 \mathrm{~mm}$ となり、 温度センサーは上から $20 \mathrm{~mm} 、 80 \mathrm{~mm} 、 140 \mathrm{~mm}$ の位置に設置した。 この結果、メッシュ総数は 216 点となっている。

図 11 はスラブの平均温度の蓄熱開始時(3:00)からの経時変化であ り、蓄熱開始時の平均温度を基準とする無次元温度で表している。

$$
\begin{aligned}
\mathrm{T}_{\mathrm{c}}{ }^{*}(\mathrm{t}) & =\frac{\mathrm{T}_{\mathrm{c}}(\mathrm{t})-\mathrm{T}_{\mathrm{c} 0}}{\mathrm{~T}_{\mathrm{c} 0}} \\
t & : \text { 蓄熱開始からの経過時間 }[\mathrm{h}] \\
T_{c}{ }^{*} & \text { : 無次元スラブ平均温度 }[-] \\
T_{c 0} & \text { : 蓄熱開始時のスラブ平均温度 }\left[{ }^{\circ} \mathrm{C}\right] \\
T_{c} & : t \text { 時間後のスラブ平均温度 }\left[{ }^{\circ} \mathrm{C}\right]
\end{aligned}
$$

これによると蓄熱開始時(3:00)と放熱終了時(翌日の 3:00)の無次元 温度差は土0.002 以内で準周期定常になっており、蓄熱の比較評価は 十分可能であるといえる。

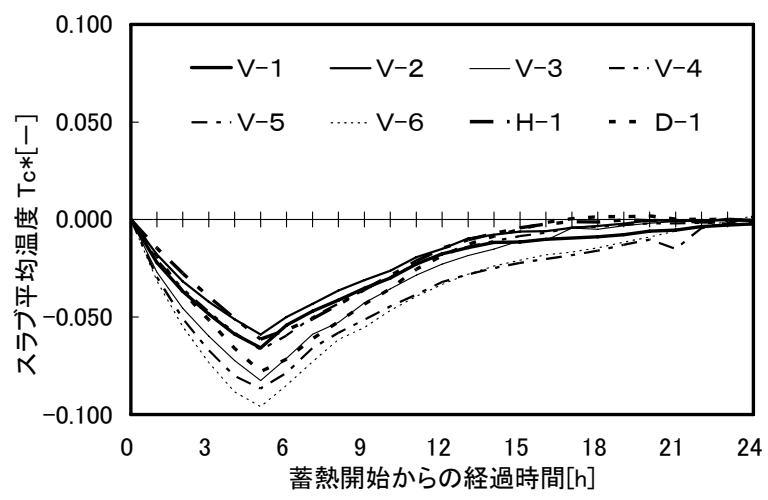

図 11 スラブ平均温度の経時変化

\section{2 スラブの平均温度、並びに蓄熱量の経時変化}

図 12 から図 19 に各ケースのスラブの平均温度、並びにスラブ全 


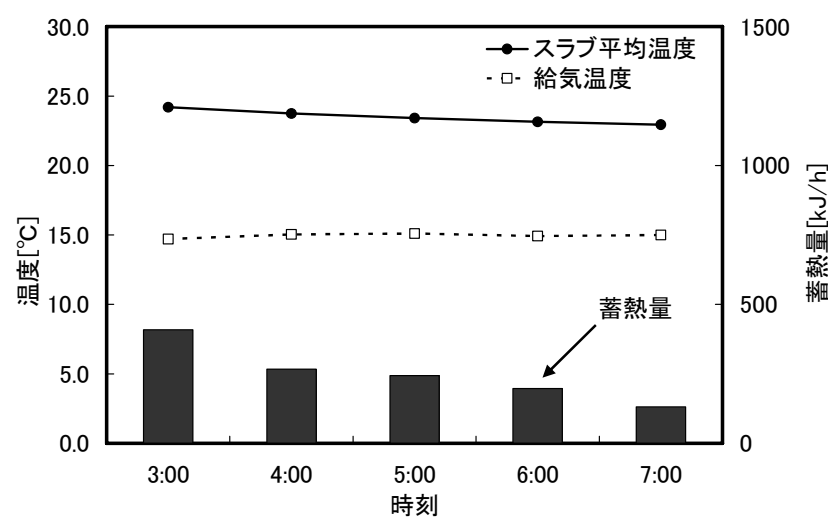

図 12 スラブ平均温度、蓄熱量、及び給気温度の経時変化 $(\mathrm{V}-1$ (標準)

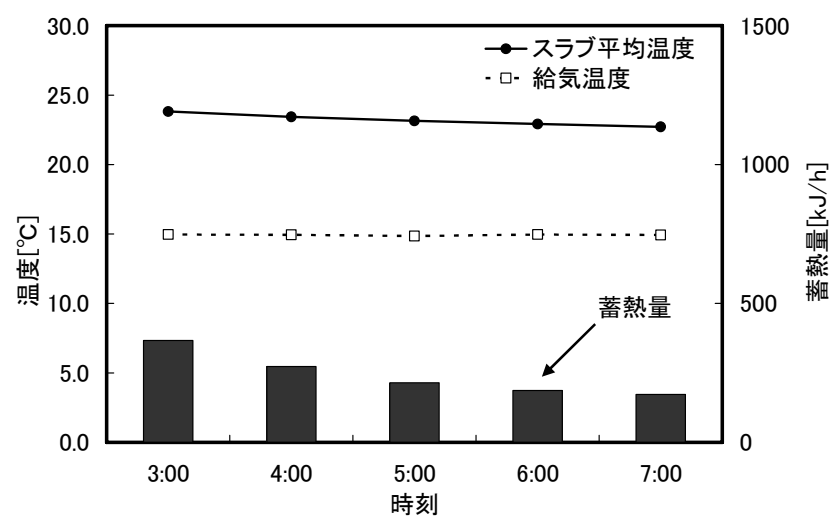

図 13 スラブ平均温度、蓄熱量、及び給気温度の経時変化 $(\mathrm{V}-2)$

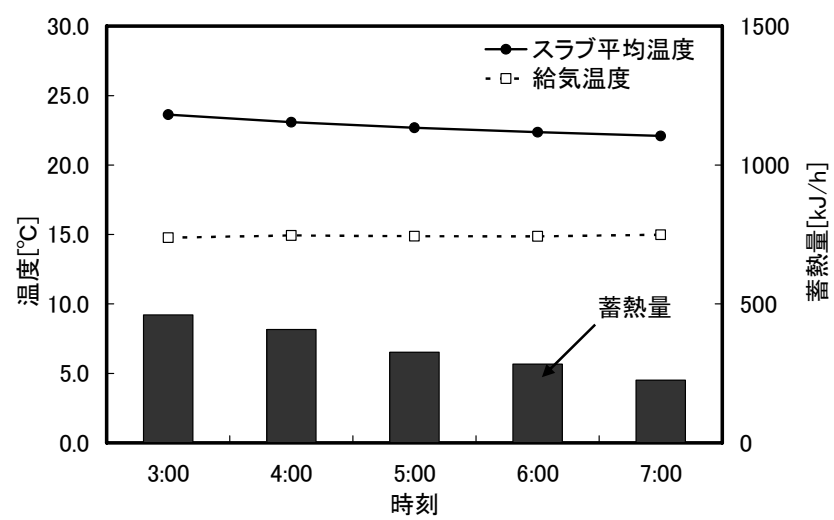

図 14 スラブ平均温度、蓄熱量、及び給気温度の経時変化 $(\mathrm{V}-3)$

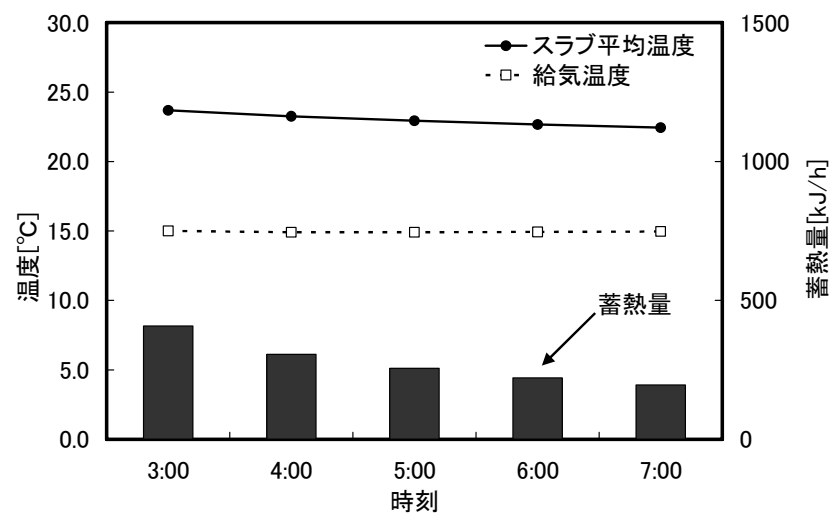

図 15 スラブ平均温度、蓄熱量、及び給気温度の経時変化 $(\mathrm{V}-4)$

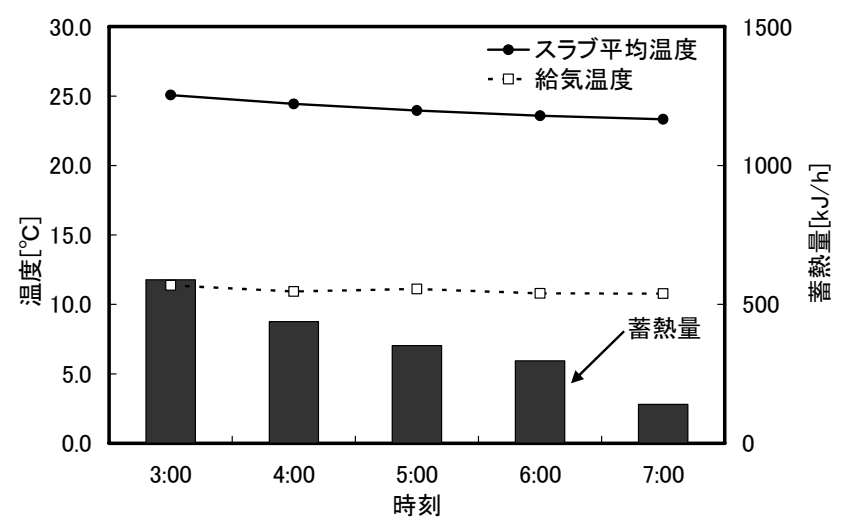

図 16 スラブ平均温度、蓄熱量、及び給気温度の経時変化 $(\mathrm{V}-5)$

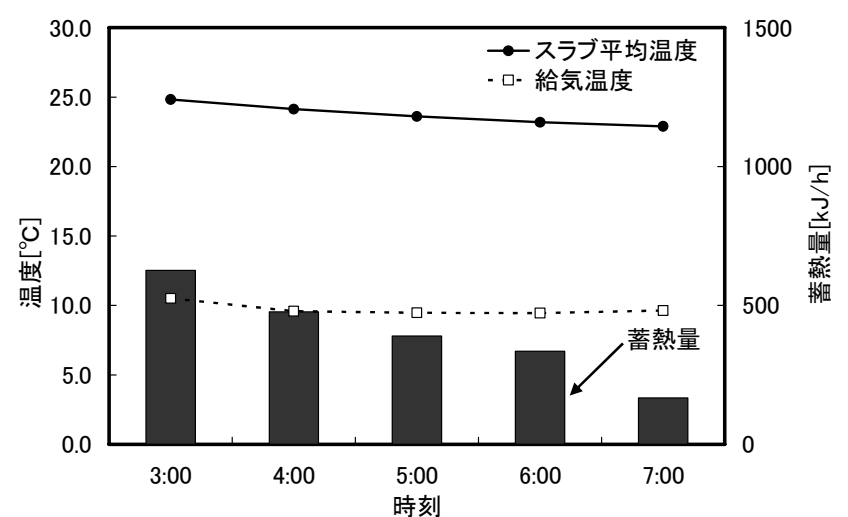

図 17 スラブ平均温度、蓄熱量、及び給気温度の経時変化 $(\mathrm{V}-6)$

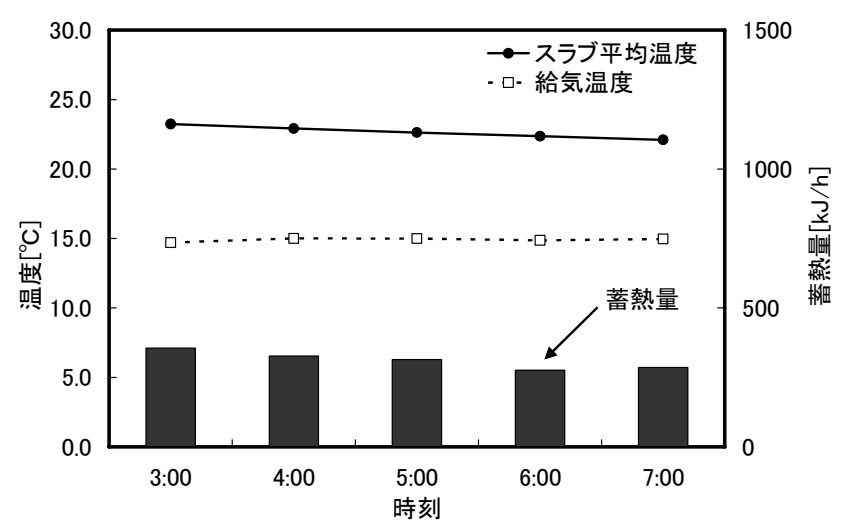

図 18 スラブ平均温度、蓄熱量、及び給気温度の経時変化 $(\mathrm{H}-1)$

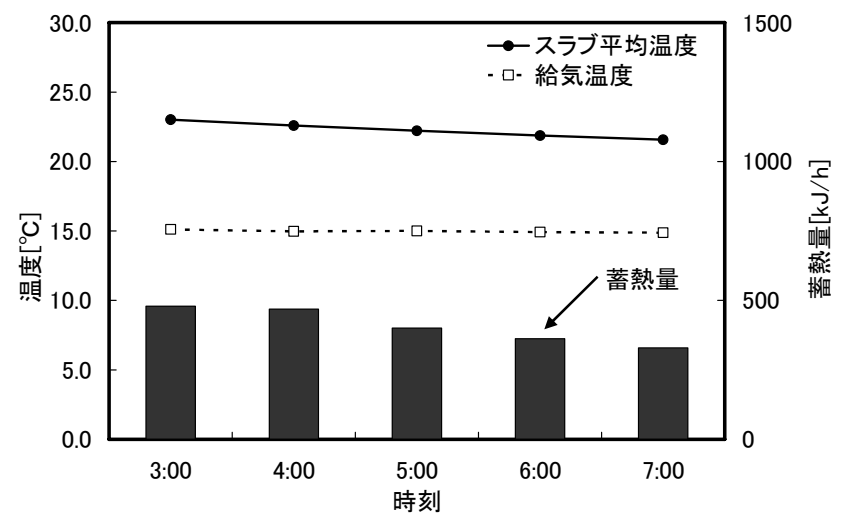

図 19 スラブ平均温度、蓄熱量、及び給気温度の経時変化 $(\mathrm{D}-1)$ 
体の蓄熱量の経時変化を示す。スラブへの蓄熱量はスラブの温度変 化より求めた。蓄熱量は前節で定めた各メッシュの温度変化に加重 平均したメッシュ体積熱容量を乗じて算出した。図中の蓄熱量は毎 正時から 1 時間後の温度差より求め、温度は毎正時から 1 時間の平 均值とした。

図 12 はV -1 の結果であるが、蓄熱時間 5 時間でのスラブの平均 温度低下は $1.3^{\circ} \mathrm{C}$ であり、スラブ全体で平均した温度低下は小さい。 また、 1 時間当たりの蓄熱量は最初の 1 時間は $409 \mathrm{~kJ}$ であるが時間 経過に従う減衰率が大きく、5 時間後には $132 \mathrm{~kJ}$ に低下している。 この傾向は試験条件により大きく異なり、例えば $\mathrm{V}-5$ では最初の 1 時間の蓄熱量は $589 \mathrm{~kJ}$ で $\mathrm{V}-1$ の 1.4 倍、 $\mathrm{V}-6$ では最初の 1 時間 の蓄熱量は $627 \mathrm{~kJ}$ で約 1.5 倍である。このように蓄熱量は吹出し温 度が低いと大きい。また、水平吹き付けの $\mathrm{H}-1$ では時間経過に従 う蓄熱量減衰率が小さく 5 時間の合計では $\mathrm{V}-1$ の 1.2 倍である。 さらに穴明きダクトの D - 1 では初期の蓄熱量も大きく、蓄熱量の 減衰率も小さくなっている。しかしながら、このままでは各ケース の比較が難いため次章でもう少し詳しい検討を行う。

\section{5。単位蓄熱量による評価法の検討}

\section{1 温度差基準の単位蓄熱量}

通常、設計時には細かい条件設定を行うことは不可能である。そ こで本論文ではまず、スラブ全体を平均して扱うこととした。これ により、今回設定するような条件では一括して本論文の結果を用い ることが出来る。ただし、今回の試験装置の加重平均スラブ厚は $126 \mathrm{~mm}$ であるので、それより大きく異なる場合は適用できない。

次に初期スラブ温度と吹出し温度を利用して、蓄熱量を両者の温 度差で除した単位温度差当たりの単位蓄熱量を評価法とすることと した。式(2)はスラブ単位面積あたり、蓄熱開始時のスラブ平均温度 と吹付け温度の温度差あたりの単位蓄熱量を表す。

$$
\alpha(\mathrm{t})=\frac{G t(\mathrm{t})}{\mathrm{S} \times\left(\mathrm{T}_{\mathrm{c} 0}-\mathrm{T}_{\mathrm{a}}\right)} \times 3.6
$$

$$
\begin{aligned}
& t: \text { 蓄熱開始からの経過時間 }[\mathrm{h}] \\
& \alpha: t \text { 時間後の単位蓄熱量 }\left[\mathrm{W} /\left(\mathrm{m}^{2} \cdot \mathrm{K}\right)\right] \\
& G t: t \text { 時間後の蓄熱量 }[\mathrm{kJ} / \mathrm{h}] \\
& S: \text { スラブ面積 }\left[\mathrm{m}^{2}\right] \\
& T_{c 0} \text { : 蓄熱開始時のスラブ平均温度 }\left[{ }^{\circ} \mathrm{C}\right] \\
& T_{a}: \text { 吹付け温度 }\left[{ }^{\circ} \mathrm{C}\right]
\end{aligned}
$$

この指標であれば実際の設計時でも簡易に利用できる実験データ となり得ると考える。図 20 は単位蓄熱量の経時変化を算出し回帰式 を導いた結果である。回帰式は式(3)で表される。試験ケース別の各 種定数、並びに相関係数を表 3 に示す。

$$
\begin{aligned}
\alpha= & a \times e^{-b t} \\
t & : \text { 蓄熱開始からの経過時間 }[\mathrm{h}] \\
\alpha & : t \text { 時間後の単位蓄熱量 }\left[\mathrm{W} /\left(\mathrm{m}^{2} \cdot \mathrm{K}\right)\right] \\
a, b & : \text { 実験定数 }[-]
\end{aligned}
$$

解析にあたって吹出し温度は蓄熱時間帯中ほぼ一定であったので蓄 熱時間での平均值を用いた。これは、実際の建物の検討では吹出し 温度の設定值を用いることができる。また、図 20 中V $-4(0)$ はV - 4 での吹出し口の無いブロック IV の蓄熱量である。このブロック は吹出し口のある最も近いブロックから大梁と小梁を越えた天井内 レターンのあるブロックである。

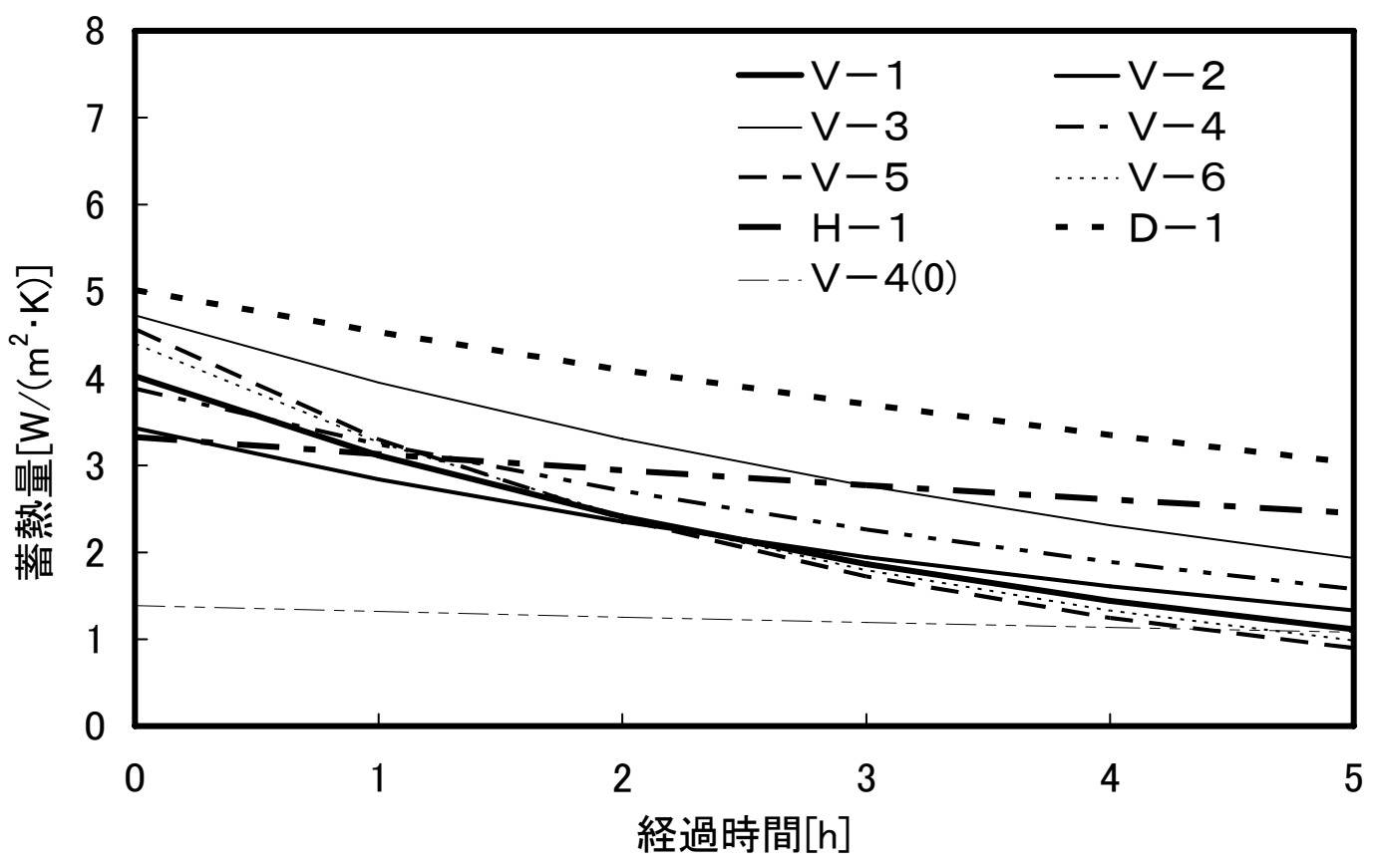

図 20 単位蓄熱量の経時変化の比較 
表 3 回帰式の定数、並びに相関係数

\begin{tabular}{|c|c|c|c|}
\hline 試験ケース & $\mathrm{a}$ & $\mathrm{b}$ & $\mathrm{R}^{2}$ \\
\hline $\mathrm{V}-1$ & 4.027 & -0.257 & 0.956 \\
\hline $\mathrm{V}-2$ & 3.430 & -0.189 & 0.945 \\
\hline $\mathrm{V}-3$ & 4.727 & -0.179 & 0.991 \\
\hline $\mathrm{V}-4$ & 3.882 & -0.180 & 0.970 \\
\hline $\mathrm{V}-5$ & 4.564 & -0.325 & 0.913 \\
\hline $\mathrm{V}-6$ & 4.398 & -0.299 & 0.911 \\
\hline $\mathrm{H}-1$ & 3.326 & -0.061 & 0.882 \\
\hline $\mathrm{D}-1$ & 5.015 & -0.101 & 0.967 \\
\hline $\mathrm{V}-4(0)$ & 1.387 & -0.050 & 0.959 \\
\hline
\end{tabular}

\section{2 単位蓄熱量による評価法の検証}

初期スラブ温度と吹出し温度の温度差で除した単位蓄熱量の妥当 性を確認するため、吹出し温度条件のみ異なる $\mathrm{V}-1\left(15^{\circ} \mathrm{C}\right.$ 吹出し)、 $\mathrm{V}-5$ ( $11^{\circ} \mathrm{C}$ 吹出し)、 $\mathrm{V}-6\left(9^{\circ} \mathrm{C}\right.$ 吹出し $)$ の 3 ケースの比較を行 った。図 21 は実測值より式(2)を用いて 5 時間の蓄熱量変化とその 合計值を示したものである。3 者は同様の変化を示し、合計值での 差は最も多い $\mathrm{V}-1$ と最も少ない $\mathrm{V}-5$ で $4 \%$ であった。このこと より、今回のデータ解析法は妥当であり、蓄熱量は初期スラブ温度 と吹出し温度の差に比例すると言える。

\section{3 単位蓄熱量を用いた評価法による蓄熱条件の影響の検討}

\subsection{1吹付け風量による影響}

まず吹付け風量による影響をみるため式(3)を用いて $\mathrm{V}-1$ $\left(28 \mathrm{~m}^{3} /\left(\mathrm{m}^{2} \cdot \mathrm{h}\right)\right)$ と $\mathrm{V}-2\left(14 \mathrm{~m}^{3} /\left(\mathrm{m}^{2} \cdot \mathrm{h}\right)\right)$ の比較を行った。図 22 が その結果である。風量の多い $\mathrm{V}-1$ は初期の蓄熱量が若干多いもの の時間経過に従い蓄熱量の減少率が大きく 5 時間経過時点では蓄熱 量の合計がほぼ等しくなっている。このことより今回の吹付け風量 範囲では風量が蓄熱量に大きな影響を与えることは無いことがわか った。

\subsection{2 吹出し口密度の影響}

次にブロック当たりの吹出し口密度による影響を確認するためブ ロック当たり吹出しロが 2 個の $\mathrm{V}-3 、 1.5$ 個の $\mathrm{V}-1$ (標準)、吹出 し口の無いV $-4(0)$ の比較を行った。図 23 がその結果である。 $V$ -3 と $\mathrm{V}-1$ (標準)は全吹出し口の合計の風量は同じであるが、吹 出し口が多く、風量が分散されているほど蓄熱量が増加している。 また、V-4(0)より吹出し口が無く天井裏を気流が通過するだけで はほとんど蓄熱が望めないのがわかる。これらのことより、蓄熱量 の増加のためには均一に多くの吹出し口を設けることが必要と言え る。また、 $\mathrm{V}-3$ はV -1 (標準)に比べ 5 時間の蓄熱量で $44 \%$ 多い。

\section{3. 3 吹付け方式による影響}

最後に吹付け方の違いによる比較を行う。図 24 によると垂直吹付 けの $\mathrm{V}-1$ (標準) と水平吹付けの $\mathrm{H}-1$ では蓄熱開始直後ではほぼ 同程度の蓄熱量であるが $\mathrm{H}-1$ は蓄熱量の減衰率が低く、蓄熱 5 時 間の合計ではV -1 (標準)の 1.4 倍となっている。これは、水平吹付 けの方がスラブに均一に気流があたりスラブ全面に蓄熱されるため と考えられる。また、同じ水平吹付けでもデッキプレートの溝に沿 って空気を吹付けるD - 1 は蓄熱初期から蓄熱終了まで絶えず蓄熱 が多くV-1 (標準)の 1.9 倍である。これは、スラブ初期温度と吹出 し温度の温度差に換算するとそれぞれ、 $1.4^{\circ} \mathrm{C}$ と $1.9^{\circ} \mathrm{C}$ に相当する。 また、同じ水平吹付けでもデッキプレートの波の方向が気流性状と 蓄熱特性に大きく影響していることがわかった。

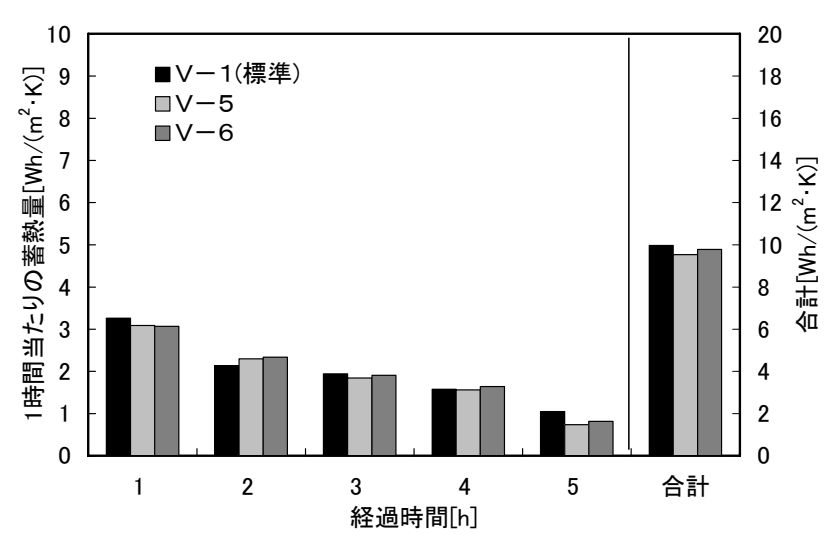

図 21 吹出し温度の違いの比較

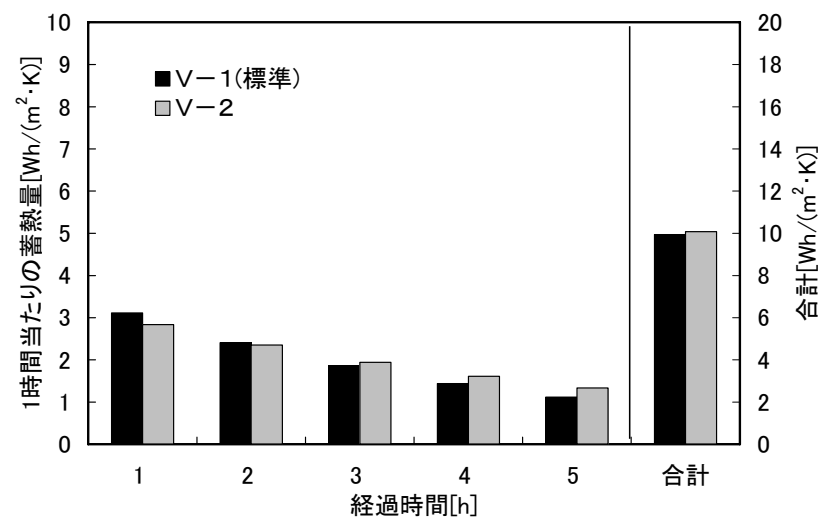

図 22 吹付け風量の違いの比較

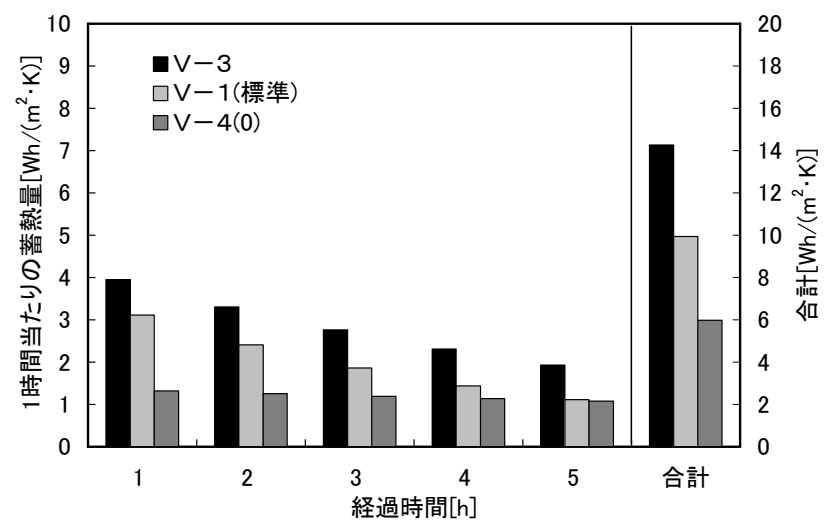

図 23 ブロック当たりの吹出し口密度の違いの比較

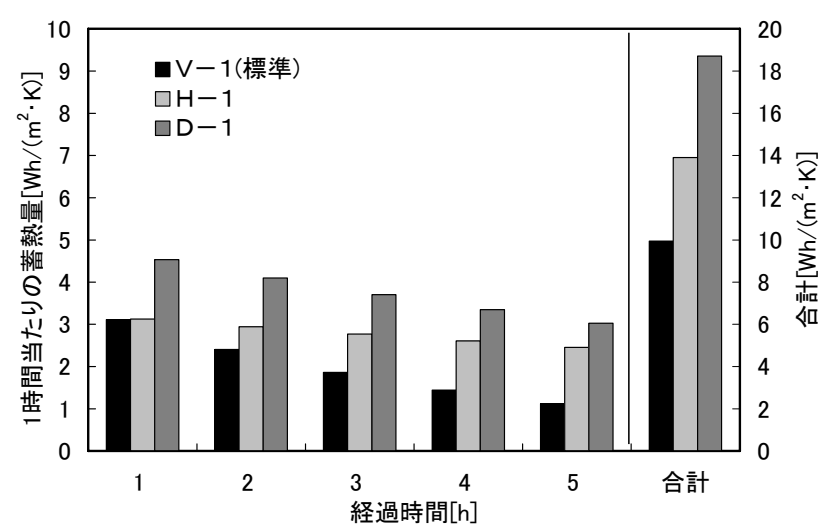

図 24 吹付け方式の違いの比較 


\section{6. まとめ}

本論文では躯体蓄熱システムに関し、再現性のある試験装置にて 蓄熱条件を変えて試験を実施した。また、その結果を用いて簡易に 蓄熱量を推定できる評価手法を検討し、それを用いて蓄熱影響因子 別の実験式を提示し、得られた成果を汎用的に利用できる形にまと めた。以下に本論文で得られた知見をまとめる。

1) 蓄熱量の評価法として初期スラブ温度と吹出し温度の温度差 で除した単位蓄熱量の実験式で表わ寸評価法を提案した。ま た、実験結果より蓄熱量がこの温度差に比例していることを 確認し、この評価法が適正であることを検証した。

2） 天井裏に供給する風量が同じでもブロック当たりの吹出し口 密度が多いと蓄熱量が多くなり、逆に吹出し口の全く無いブ ロックでは蓄熱がほとんど見込めないことがわかった。今回 の条件ではブロック当たりの吹出しロが 2 個の場合、 1.5 個の 場合比較して蓄熱量が $44 \%$ 多くなった。

3）吹付け方式による影響は大きく、今回標準とした垂直吹付け に比べて水平吹付けでは 1.4 倍、デッキプレートの波に沿って 気流を吹付ける方式ではさらに多く 1.9 倍の蓄熱量が得られ ることがわかった。

最後に実験から得られた知見より、効率的な蓄熱条件をまとめる。

1) まず、吹付け方式ではスラブに水平に吹付ける方式が効率が 高く、特にデッキプレートの波に沿って吹付けると蓄熱量が 増加する。

2) 次に吹付け風量に関しては、今回の床面積当たりの風量 14〜
$28 \mathrm{~m}^{3} /\left(\mathrm{m}^{2} \cdot \mathrm{h}\right)$ の範囲では蓄熱量に大きな差が見られなかった。 そのため、送風エネルギーの点からは夜間の風量を半分程度 にする検討が必要である。

3) 吹出し口の密度に関してはブロック(梁で囲まれた天井裏面積、 今回は約 $\left.16 \mathrm{~m}^{2}\right)$ 当たり最低 1 個の吹出し口が必要である。

4) 吹出し温度に関しては当然のことながら蓄熱量と吹出し温度 とスラブの温度差は比例関係となる結果が得られた。そのた め蓄熱量の増減をさせるには、この温度差で調整が可能であ る。

\section{参考文献}

1)小久保吉章、川島実、福村貴司、那須原和良 : 躯体蓄熱を利用した空調 システムの開発(その $1:$ 試験装置概要)、日本建築学会大会学術講演梗 概集（環境工学 II）、pp.1009-1010、1999.9

2)川島実、中村卓司、野部達夫、大崎裕史 : 躯体蓄熱を利用した空調シス テムの開発(その 4 : 試験条件と室温スラブ温度挙動)、日本建築学会大 会学術講演梗概集（環境工学 II）、pp.1017-1018、2000.9

3)中村卓司、竹林芳久、福村貴司、小久保吉章 : 躯体蓄熱を利用した空調 システムの開発(その 5 : 試験結果の解析)、日本建築学会大会学術講演 梗概集（環境工学 II）、pp.1019-1020、2000.9

(2007年 9 月10日原稿受理，2008年 1 月23日採用決定） 